\title{
EMPLOYEE PERFORMANCE PT. MILLENIUM PHARMACON INTERNATIONAL Tbk: QUALITY OF HUMAN RESOURCES (HR) AND INFORMATION SYSTEMS OF MILLENIUM PHARMACON INTERNATIONAL (SIMPI)
}

\author{
Eka Lufitasari ${ }^{1}$, Mochamad Mochklas ${ }^{2 *}$, Djoko Soelistya ${ }^{3}$ \\ ${ }^{1,2,3}$ Fakultas Ekonomi dan Bisnis, Universitas Muhammadiyah Surabaya, \\ Email: mmochklas@fe.um-surabaya.ac.id
}

\begin{abstract}
Companies must be able to compete, so it requires quality human resources (HR) and technology in the form of applications implemented by the company that can assist in achieving the company's vision and mission. This research aims to analyze the influence of the quality of human resources and the Millennium Pharmacon International (SIMPI) Information System Application on the Performance of PT. Millenium Pharmacon International Tbk. This study uses a quantitative approach, where the population and research sample of all employees of PT. Millenium Pharmacon International Tbk. Surabaya branch as many as 85 people. The incoming data is processed and analyzed using the SPSS-26 program. The results of this study the quality of human resources has a positive but insignificant effect on the performance of employees of PT. Millenium Pharmacon International Tbk, SIMPI has a positive and significant effect on the employee performance of PT. Millenium Pharmacon International Tbk, and the quality of $H R$ and SIMPI simultaneously have a positive and significant effect on the performance of employees of PT. Millenium Pharmacon International Tbk.
\end{abstract}

Keywords: Quality of Human Resources, SIMPI, Employee Performance

\section{Introduction}

PT. Millenium Pharmacon International Tbk. (PT. MPI) is engaged in the distribution of medicines as well as medical devices. In the practice of its activities, PT. MPI as a distributor has a warehouse so that it can accommodate stocks of medicines as well as medical devices from several cooperating principals such as PT. Lapi Laboratories, PT. Guardian PH, PT. Simex, PT. Dipa Pharma, and so on. As time goes by, now other distributor companies have sprung up and business competition is getting tougher. Even though they are engaged in the same field, drug and medical equipment distributor companies have different visions and missions as well as human resource management.

All employees at PT. MPI is required to work according to the target and be able to bring out the best potential in completing its work. According to (Budiyanto \& Mochklas, 2020: 2) the contribution of employees to the company will determine the progress or decline of the company, where the contribution of employees to the organization is shown by effective actions and behaving correctly, not only the number of efforts but also the direction of the business. PT. MPI has also made efforts to be able to maximize the company's human resources, namely by carrying out the process of improving employee performance assisted by a system, namely the Millennium Pharmacon International Information System (SIMPI). Even so, there are still problems at work such as: employees of PT. MPI is more male than female. This is shown in table 1 below: 
International Journal of Economics, Business and Accounting Research (IJEBAR)

Peer Reviewed - International Journal

Vol-4, Issue-3, 2020 (IJEBAR)

E-ISSN: 2614-1280 P-ISSN 2622-4771

http://jurnal.stie-aas.ac.id/index.php/IJEBAR

Table 1. Employee data based on Gender

\begin{tabular}{ccc}
\hline Gender & Total & Percentage \\
\hline Male & 65 & $76 \%$ \\
Women & 20 & $24 \%$ \\
\hline total & 85 & $100 \%$ \\
\hline Source: BFO data of companies processed, 2020
\end{tabular}

From table 1., which is sourced from the company's BFO (Branch Finance Operations), it is noted that the number of male employees is $76 \%$ and only $24 \%$ female employees, at PT MPI, so that the responsibility for work in the company is mostly done by male employees. men. So that problems arise in recording, such as when stock taking occurs when there is a difference in stock, reports made by employees are less clear in writing, sometimes less accurate, and need to be asked again so that the time spent correcting is wasted a lot.

Apart from the above problems, PT. MPI also has the most employees who are SLA graduates. According to Juliana, et al. (2015) and Ratnasari \& Sunuharyo (2018) that education has a significant effect on employee performance. The higher the age and complexity of the task, the lower the effectiveness of users of the accounting information system. While work experience and education level have a positive effect on the effectiveness of users of accounting information systems (Anjani, et al. 2018).

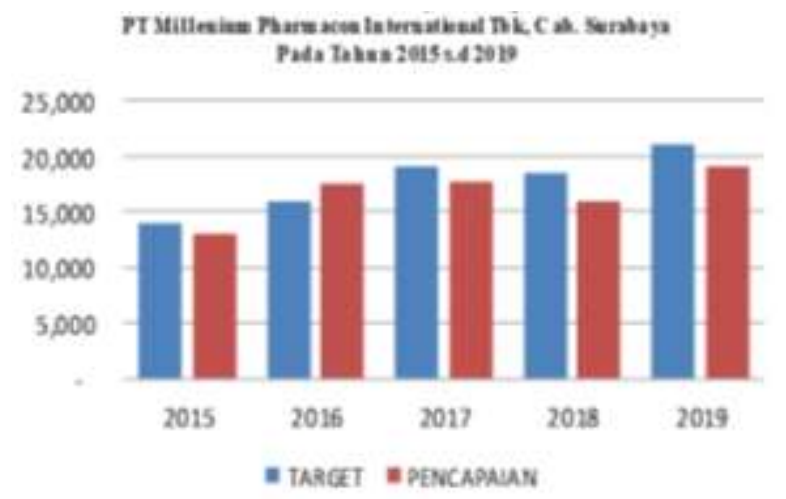

Figure 1. Sales Target Achievement Trend

Source: BFO data of companies processed, 2020

From Figure 1, there is a decrease in the achievement of the target in 2017 to 2019, so it is necessary to evaluate the problems that arise in the company so that employee performance increases so that company profits also increase again. One way to improve company performance can be done by improving the quality of human resources (Fuad, et al. 2017). Employees with good quality human resources will most likely achieve the targets given by the company which will lead to better employee performance.

The research results of Aisyah, et al. (2017) the quality of human resources has a positive and significant effect on employee performance. The quality of human resources affects financial performance (Siregar, 2019). Ananda, et al. (2019) stated that the quality of human resources directly and indirectly has a positive and significant effect on the work effectiveness of implementing employees.

Work is done with the help of technology in the form of applications that are likely to be completed faster and more effectively so that employee performance increases. According to (Pamungkas, 2017), the work management information system can be done quickly, precisely, and organized, and the management information system can be used as material for planning, decision making and evaluation. So 
International Journal of Economics, Business and Accounting Research (IJEBAR)

Peer Reviewed - International Journal

Vol-4, Issue-3, 2020 (IJEBAR)

E-ISSN: 2614-1280 P-ISSN 2622-4771

http://jurnal.stie-aas.ac.id/index.php/IJEBAR

that employees can work easily with report quality in accordance with applicable standards, companies must provide software facilities that can support the information system process (Febriansyah, 2018).

From the research results of Arsiningsih, et al. (2015) there is a positive and significant influence between the use of information technology on employee performance, Rusjiana (2016) HR information systems have an effect on employee performance.

It is very important to analyze the quality of human resources and the SIMPI application of PT Millenium Pharmacon International Tbk, Surabaya Branch in order to improve employee performance, because the quality of human resources on work performance (Leuhery, 2018), the quality of human resources and the effectiveness of using SIDUPA have a positive and significant effect on employee performance (Yohana, 2019). The purpose of this research is to analyze the influence of the quality of human resources and the MPI Information System application on the performance of employees of PT. Millenium Pharmacon International Tbk, Surabaya Branch.

\section{Theoretical Basis}

\section{Employee performance}

Performance is the result that has been achieved by employees according to the requirements set in the job (Bangun, 2012: 231). The results achieved by a person or the quantity and quality that are accounted for according to the tasks assigned by the company to him (Mangkunegara, 2016: 67). The results that have been achieved by each employee in a company are used to measure the performance of the employee (Roziqin, 2010: 41). The work performance of each employee must be measurable and achievable in the period set in the company (Edison, 2016: 190).

\section{Quality of Human Resources}

The quality of human resources is a guideline for determining quality human resources. According to Sedarmayanti (2009: 59) the quality of human resources is a measure of the extent to which requirements, specifications and expectations have been met. The quality of human resources, namely (Ndraha, 2012: 12). Rahardjo's opinion (2010: 18) states that the quality of human resources is not seen from the physical, but also in terms of education, experience, and the maturity of individual attitudes in the company environment.

Quality of human resources is the fulfillment of requirements, specifications, and expectations where the quality of human resources is not seen from the physical, but also in terms of education, experience, maturity of individual attitudes within the company so that human resources are able to realize values, not only comparative values but also other values. such as being innovative, generative, and competitive, using the highest energies like imagination, creativity and intelligence.

\section{Millenium Pharmacon International Information System (SIMPI)}

The system is a component that is in a company that has mutual relations and is able to support company performance (Fahmi, 2016: 199). The information system is a system within an organization that brings together the needs of transaction processing, supports operations, is managerial and strategic activities of an organization and provides certain external parties with the necessary reports (Mochklas \& Setiawan, 2018: 3).

Millenium Pharmacon International Information System (SIMPI) is a system specially designed and designed to assist the completion of company administration in various fields/positions of PT. Millenium Pharmacon International Tbk. This system is designed based on the needs and continuation of the previous system, namely oracle (manual). The Oracle system is the company's main system used in all branches. 
International Journal of Economics, Business and Accounting Research (IJEBAR)

Peer Reviewed - International Journal

Vol-4, Issue-3, 2020 (IJEBAR)

E-ISSN: 2614-1280 P-ISSN 2622-4771

http://jurnal.stie-aas.ac.id/index.php/IJEBAR

\section{Research Methods}

This research approach is a quantitative research approach with explanative research using a sample taken from the population using a questionnaire as a tool to collect primary data and individual analysis units. Where the population and sample of employees of PT. Millenium Pharmacon International Tbk, Surabaya branch totaling 85 respondents.

The research hypothesis is:

H1: The quality of human resources has a positive and significant effect on the performance of employees of PT. Millenium Pharmacon International Tbk.

H2: SIMPI has a positive and significant effect on the employee performance of PT. Millenium Pharmacon International Tbk,.

H3: The quality of human resources and SIMPI applications simultaneously have a positive and significant effect on the performance of employees of PT. Millenium Pharmacon International Tbk.

\section{Results and Discussion}

\subsection{Research Result}

\section{Classic assumption test}

Normality test

Based on the test results through SPSS version 26, it is known the results of the normality test with a significance value of $0.078>0.05$. In conclusion, the residual value in this study is normally distributed.

\section{Multicolonierity Test}

Based on the test results through SPSS version 26, it can be seen that the tolerance value is 0.624 , which means that the value is $0.624>0.1$, based on the tolerance value, there is no multicollinearity symptom. The VIF value is 1.603 , which means that the value is $1.603<10$, so there are no symptoms of multicollinearity. Based on the tolerance and VIF values, it can be concluded that the regression model influences the quality of HR and the SIMPI application on the employee performance of PT. Millenium Pharmacon International Tbk, Surabaya branch had no symptoms of multicollinearity.

Heteroscedasticity Test

Based on the test results through SPSS version 26, it can be seen that the quality of human resources variable has a significance value of 0.106 and the SIMPI application variable has a significance value of 0.121 , meaning that the value is greater than 0.05 . The conclusion is the regression model of the influence of the quality of human resources and the SIMPI application on employee performance, there is no heteroscedasticity problem as evidenced by the significance value $>0.05$.

\section{Autocorrelation}

Based on the test results through SPSS version 26, the D-W (Durbin-Watson) value is 1,607, this indicates that the D-W value is between $(-) 2$ to $(+) 2$, so it can be stated that there is no autocorrelation.

\section{Multiple Linear Regression Analysis}

Table 2. Results of Multiple Regression Test Analysis Coefficients $^{\mathrm{a}}$

\begin{tabular}{llccccc} 
Model & \multicolumn{3}{c}{$\begin{array}{c}\text { Unstandardized } \\
\text { Coefficients }\end{array}$} & Standardized \\
Coefficient & & Sig. \\
1 & & B & Std. Error & Beta & t & Sig. \\
& (Constant) & 24.335 & 2.891 & & 0.417 & 0.000 \\
& Quality of HR & 0.207 & 0.265 & 0.100 & 0.782 & 0.436 \\
& SIMPI & 0.325 & 0.125 & 0.332 & 2.596 & 0.011
\end{tabular}

a. Dependent Variable: Employee Performance 
International Journal of Economics, Business and Accounting Research (IJEBAR)

Peer Reviewed - International Journal

Vol-4, Issue-3, 2020 (IJEBAR)

E-ISSN: 2614-1280 P-ISSN 2622-4771

http://jurnal.stie-aas.ac.id/index.php/IJEBAR

Source: Researcher data processed (2020)

Based on table 2, it can be seen that the regression equation formed in the regression test is as follows:

$$
\mathrm{Y}=24.335+0.207 \mathrm{X} 1+0.325 \mathrm{X} 2+\mathrm{e}
$$

The interpretation of the above model is as follows:

- The constant (a) is 24,335 , meaning that if the independent variable is the quality of human resources and the SIMPI application is constant, then the employee performance dependent variable is 24,335 units.

- The quality of human resources has a coefficient value of 0.207 . This shows that the quality of human resources has a positive influence on employee performance. If the quality of human resources increases by one unit, it means that the higher the value of the quality of the human resources, the higher the employee's performance.

- The SIMPI application has a coefficient of 0.325. This shows that the SIMPI application has a positive effect on employee performance (Y). If the SIMPI application value increases by one unit, it means that the higher the SIMPI application value, the employee performance will increase.

\section{Hypothesis testing}

T test

The results of the $t$ test in this study were processed with SPSS version 26 as follows:

Table 3. T test results

Coefficients $^{\mathrm{a}}$

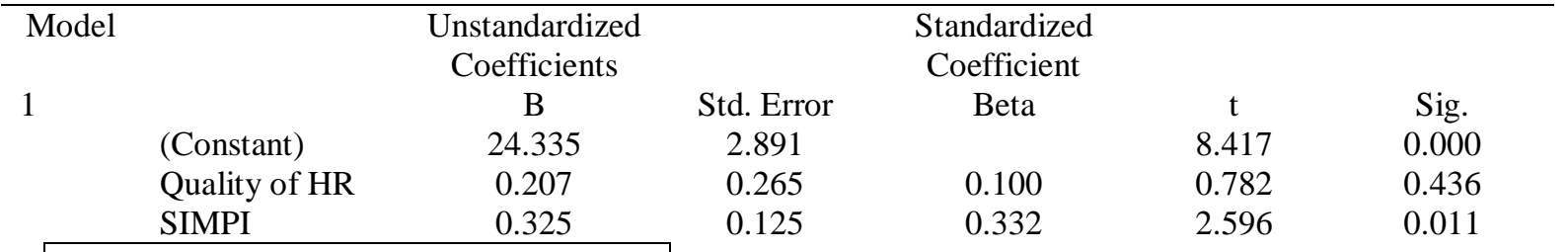

a. Dependent Variable: Employee Performance

Source: Researcher data processed (2020)

The interpretation of the $t$ test is as follows:

- Partial Test between Independent Variables Quality of Human Resources, on Employee Performance, with a significance value $=0.436$. The significance value of the quality of human resources variable is $0.436>0.05$, this shows that the variable quality of human resources partially has no effect on employee performance. So $\mathrm{H} 1$ is rejected

- Partial Test between SIMPI Applications, on Employee Performance (Y), with a significance value of 0.011 . The significance value of the HR Quality variable (X1) $0.011<0.05$, this shows that the SIMPI application variable partially affects employee performance (Y). So H2 is accepted.

F test

From the results of data processing using SPSS version 26, the results are as follows:

Table 4. F Test Results

\begin{tabular}{lrrrrrr}
\multicolumn{7}{c}{ ANOVA $^{\mathrm{a}}$} \\
\hline Model & & Sum of & df & Mean & F & Sig \\
& & Squares & & Square & & \\
1 & Regression & 119.404 & 3 & 59.702 & 7.892 & $.001^{\mathrm{b}}$
\end{tabular}

International Journal of Economics, Business and Accounting Research (IJEBAR)

Page 260 
International Journal of Economics, Business and Accounting Research (IJEBAR)

Peer Reviewed - International Journal

Vol-4, Issue-3, 2020 (IJEBAR)

E-ISSN: 2614-1280 P-ISSN 2622-4771

http://jurnal.stie-aas.ac.id/index.php/IJEBAR

$\begin{array}{llll}\text { Residual } & 620.290 & 82 & 7.565 \\ \text { Total } & 739.694 & 84 & \end{array}$

a. Dependent Variable: Employee Performance

b. Predictors: (Constant), SIMPI, Quality of HR

Source: Researcher data processed (2020)

From the results of the processing of the $\mathrm{F}$ test in table 4, it is known that the significance value is $0.001<0.05$, this indicates that the quality of human resources and the SIMPI application simultaneously has a significant effect on employee performance.

Coefficient of Determination

Based on the calculation of SPSS 26, the results of the correlation coefficient of determination $\mathrm{R}^{2}$ are obtained in table 5 below:

Table 5. Coefficient of Determination Results Model Summary ${ }^{\text {b }}$

\begin{tabular}{cccccc}
\hline Model & $\mathrm{R}$ & R Square & Adjusted R Square & Std. Error of the & Durbin \\
& & & & Estimate & Watson \\
1 & $.402^{\mathrm{a}}$ & 0.161 & 0.141 & 2.75037 & 1.607 \\
\hline
\end{tabular}

a. Predictors: (Constant), SIMPI, Quality of HR

b. Dependent Variable: Employee Performance

Source: Researcher data processed (2020)

Based on the results in table 5, the value of the determinant coefficient is 0.161 , meaning that the independent variable of HR quality and the SIMPI application has an influence on employee performance by $16.1 \%$ or 16.1 employee performance can be explained by the variable quality of human resources and the SIMPI application. As for the remaining $83.9 \%$, it is influenced by other variables not included in this study.

\subsection{Discussion}

\section{Effect of HR Quality on Employee Performance}

From the results of the study shows the magnitude of the influence of the quality of human resources on employee performance is 0.100 which means there is a positive influence. The significance test shows that the value of 0.436 is greater than 0.05 , so it is not significant. From these results the first hypothesis, that the quality of human resources has a positive and significant effect on the performance of employees of PT Millenium Pharmacon International Tbk, Surabaya branch is rejected.

The findings of this study are in line with research by Sibagariang (2018) that the quality of human resources has no significant effect on performance. And rejecting the research results of Sudarsih (2017), Aisyah, et al. (2017), Siregar (2019) and Ananda, et al. (2019) which states that the quality of HR has a positive and significant effect on employee performance.

In order for the quality of human resources to increase, companies need to provide training to employees (Sutrisno, 2016: 151). To improve employee competence through continuous education and training so that employee knowledge and skills can increase in accordance with business development (Pattiasina, et al., 2016). The effectiveness of education and training programs for employees to better suit the needs of employees, namely by increasing the work ability of employees through knowledge sharing so that they are more skilled in carrying out their jobs. Companies must also provide encouragement in the form of incentives, rewards, and opportunities to develop self-potential so that they are more motivated to produce products according to company targets and standards (Ratnasari \& Sunuharyo, 2018). 
International Journal of Economics, Business and Accounting Research (IJEBAR)

Peer Reviewed - International Journal

Vol-4, IsSue-3, 2020 (IJEBAR)

E-ISSN: 2614-1280 P-ISSN 2622-4771

http://jurnal.stie-aas.ac.id/index.php/IJEBAR

\section{The Effect of SIMPI on Employee Performane}

From the research results show the magnitude of the influence of the SIMPI application on employee performance is 0.332 which means there is a positive influence. The significance test shows that the value of 0.001 means that it is smaller than 0.05 , it is significant. From these results the second hypothesis, that SIMPI has a positive and significant effect on the performance of the employees of PT. Millenium Pharmacon International Tbk, Surabaya branch accepted. The findings of this study support the research of Arsiningsih, et al. (2015), Rusjiana (2016) and Yohana (2019) that information systems have a positive and significant effect on employee performance.

Application-Based Information Systems The Purpose To Support Business Processes (Skawanti, 2018). By Providing Software Facilities That Can Support The Information System Process Employees Can Be Provided Ease Of Work And The Quality Of The Reports That Are Presented In Accordance With The Applicable Standards. (Febriansyah, 2018). So that the existence of the SIMPI application has an effect on the performance of employees who are able to support the company's goals.

\section{The Influence of HR Quality and SIMPI on Employee Performance}

The results showed the magnitude of the effect of the quality of human resources and the SIMPI application $(+0.161)$ and the significance value was 0.001 , which is less than 0.05 . From these results the third hypothesis, that the quality of human resources and SIMPI simultaneously have a positive and significant effect on the performance of employees of PT. Millenium Pharmacon International Tbk., Accepted. The findings of this study support Yohana's (2019) research, namely the quality of human resources and the effectiveness of using SIDUPA have a positive and significant effect on employee performance.

According to Jaryono \& Widuri (2013), it is necessary to improve the quality of human resources who have direct duties on the Information Technology (IT) component, namely by providing opportunities for employees to take part in IT training related to their duties, so that their abilities will increase. Training does not have to wait for requests from trainees from related institutions, but must be proactive by involving employees at institutions that are competent in the IT field. The use of IT in the company should be adjusted to the needs, so that the budget spent will be more useful. The use of appropriate information technology without difficulty is the hope of all parties. Thus in the technology resource procurement system, it is necessary to pay attention to several things related to the needs of the company, such as from a financial perspective, the orientation of application development so that it will be more effective because it is in accordance with the needs.

\section{Conclusions and Suggestions}

Based on the results that have been obtained, it can be concluded that the quality of human resources has a positive but not significant effect on the performance of the employees of PT. Millenium Pharmacon International Tbk, Surabaya branch, SIMPI application has a positive and significant effect on employee performance of PT. Millenium Pharmacon International Tbk, Surabaya branch, and the quality of human resources and SIMPI applications simultaneously have a positive and significant effect on the performance of employees of PT. Millenium Pharmacon International Tbk.

The suggestions that can be submitted by the author based on the results that have been obtained include:

- The quality of human resources affects the results of employee performance, so the company is expected to understand the competencies that employees must have through enhancing and developing human resources.

- The SIMPI application is very helpful and influences the performance of employees in carrying out work tasks effectively and efficiently. Therefore the company is expected to provide time and opportunities to increase knowledge and skills in the use of information systems. 
International Journal of Economics, Business and Accounting Research (IJEBAR)

Peer Reviewed - International Journal

Vol-4, Issue-3, 2020 (IJEBAR)

E-ISSN: 2614-1280 P-ISSN 2622-4771

http://jurnal.stie-aas.ac.id/index.php/IJEBAR

- Because performance is greatly influenced in addition to the quality of human resources and the SIMPI application, it is hoped that the company will also think about other factors that support performance such as compensation, comfort, and career advancement for employees.

The limitation of this research is that the research data collection is only conducted at PT.

Millenium Pharmacon International Tbk Surabaya branch, further research can be expanded so that better results are obtained.

\section{References}

Aisyah, M.F., Utami, W., \& Sunardi, S. 2017. Kualitas Sumber Daya Manusia, Profesionalisme Kerja, Dan Komitmen Sebagai Faktor Pendukung Peningkatan Kinerja Karyawan PDAM Kabupaten Jember. e-Journal Ekonomi Bisnis dan Akuntansi, 4(1) :131-135

Ananda, F.R., Lubis, J.Y., \& Syaifuddin. 2019. Pengaruh Kualitas Sumber Daya Manusia Terhadap Efektivitas Kerja Dan Implikasinya Terhadap Kinerja Karyawan Pelaksana di PT. Perkebunan Nusantara III (Persero). Agrica (Jurnal Agribisnis Sumatera Utara), 12(2): 103-109

Anjani, P.W., \& Wirawati, N,G,P. 2018. Pengaruh Usia, Pengalaman Kerja, Tingkat Pendidikan, dan Kompleksitas Tugas terhadap Efektivitas Pengguna Sistem Informasi Akuntansi. E-Jurnal Akuntansi Universitas Udayana, 22(3): 2430-2457

Arsiningsih, N.L.F., Diatmika, I.P.G., \& Darmawan. I.N.A.R. 2015. Pengaruh Penggunaan Teknologi Informasi, Efektivitas Sistem Informasi Akuntansi, Kepercayaan Atas Sistem Informasi Akuntansi, Sistem Pengendalian Intern Terhadap Kinerja Karyawan Pada Bank Perkreditan Rakyat Di Kabupaten Buleleng Dan Bangli. e-Journal S1 Akuntansi Universitas Pendidikan Ganesha, 3(1)

Budiyanto, E., \& Mochklas, M. 2020. Kinerja Karyawan Ditinjau dari Aspek Gaya Kepemimpinan, Budaya Organisasi Dan Motivasi Kerja (Pendekatan Riset). Banten: CV. AA. Rizky

Fahmi, I. (2016). Manajemen Sumber Daya Manusia, Teori dan Aplikasi. Bandung: Alfabeta.

Febriansyah, M. 2018. The Influence Of Accounting Information System On Employee's Performance At Gapensi Jabar. Jurnal Riset Akuntansi, 10(1): 89-102

Fuad, N., Adolfina \& Trang, I. 2017. Pengaruh Kualitas Sumber Daya Manusia Dan Daya Saing Terhadap Kinerja Organisasi (Studi Pada Koperasi Anugrah Mega Mandiri Manado). Jurnal EMBA: Jurnal Riset Ekonomi, Manajemen, Bisnis dan Akuntansi, 5(2):1653-1663

I Putu Indra Yohana. 2019. Analisis Pengaruh Kualitas SDM Dan Efektifitas Penggunaan SIDUPA Pada Kinerja Pegawai Di Kabupaten Badung. Jurnal Ilmiah Media Sisfo, 13(1): 69-83

Jaryono \& Widuri, R. 2013. Analisis Pengaruh Kinerja Teknologi Informasi Terhadap Kinerja Karyawan Administrasi Fakultas Ekonomi Unsoed. JP Fakultas Ekonomi dan Bisnis Unsoed, 8(1):1-15

Juliana, Hakim, L., \& Mustari, N. 2015. Pengaruh Tingkat Pendidikan Terhadap Kinerja Pegawai Di Badan Perencanaan Pembangunan Daerah Kabupaten Enrekang. Kolaborasi: Jurnal Administrasi Publik, 1(1):11-19 
International Journal of Economics, Business and Accounting Research (IJEBAR)

Peer Reviewed - International Journal

Vol-4, Issue-3, 2020 (IJEBAR)

E-ISSN: 2614-1280 P-ISSN 2622-4771

http://jurnal.stie-aas.ac.id/index.php/IJEBAR

Leuhery, F. 2018. Pengaruh Kualitas Sumber Daya Manusia, Disiplin Kerja, Dan Pengembangan Karir Tehadap Prestasi Kerja Pegawai Dinas Perhubungan Provinsi Maluku. Jurnal SOSOQ, 6(1):118133

Mangkunegara, A. A.A.P. 2016. Manajemen Sumber Daya Manusia Perusahaan. Bandung : PT. Remaja Rosdakarya

Mochklas, M., \& Wibowo, T.S. 2018. Sistem Informasi Manajemen. Surabaya: TS. Publisher

Pamungkas, I.B. 2017. Pengaruh Sistem Informasi Manajemen, Kompetensi, Motivasi Terhadap Kinerja Karyawan Pada PT. Circleka Indonesia Utama (Wilayah Jakarta). Jurnal KREATIF : Pemasaran, Sumberdaya Manusia dan Keuangan, 5(1):18 - 29

Pattiasina, M., Roring, M., \& Rumawas, W. 2016. Pengaruh Kompetensi Sumber Daya Manusia Terhadap Kinerja Karyawan PT.Bank Tabungan Negara, Tbk. Kantor Cabang Manado. Jurnal Administrasi Bisnis, 4(2):1-6

Ratnasari, M.D., \& Sunuharyo, B.S. 2018. Pengaruh Pendidikan Dan Pelatihan Terhadap Kinerja Karyawan Melalui Variabel Mediator Kemampuan Kerja Karyawan (Studi Pada Karyawan PT. Petrokimia Gresik). Jurnal Administrasi Bisnis (JAB), 58(1):210-218

Rusjiana, J. 2016. Pengaruh Sistem Informasi SDM Terhadap Kinerja Karyawan Di PT. Rabbani Bandung. Jurnal Computech \& Bisnis, 10(1): 21-29

Siregar, M. 2019. Pengaruh Kualitas Sumber Daya Manusia dan Kualitas Anggaran Terhadap Kinerja Keuangan Daerah Dimediasi Dengan Sistem Informasi Manajemen Daerah. Maneggio: Jurnal Ilmiah Magister Manajemen, 2(2):160-169

Skawanti, J.R. (2018). Perencanaan Strategi Sistem Informasi pada Perusahaan Farmasi. Komputasi: Jurnal Ilmiah Ilmu Komputer dan Matematika, 5(2): 187-194

Sugiyono. (2019). Metode Penelitian Kuantitatif Kualitatif dan R\&D. Bandung: Alfabeta.

Sutrisno, E. (2016). Manajemen Sumber Daya Manusia. Cetakan ke-8. Jakarta: Prenada Media Group. 